\title{
Enhancing Organizational Performance through Human Resource Outsourcing in the Nigerian Deposit Money Banks
}

\author{
Olannye A. P. ${ }^{1} \&$ Okoro O. M. ${ }^{1}$ \\ ${ }^{1}$ Department of Business Administration and Marketing, Faculty of Management Sciences, Delta State University, \\ Asaba Campus, Nigeria \\ Correspondence: Dr. Olannye A. P., Department of Business Administration and Marketing, Faculty of Management \\ Sciences, Delta State University, Asaba Campus, Nigeria.
}

Received: July 30, 2017

doi:10.5430/jms.v8n4p67
Accepted: August 10, 2017

Online Published: August 21, 2017

URL: https://doi.org/10.5430/jms.v8n4p67

\begin{abstract}
As competition rages on in the business environment, the demand for increased productivity, profitability with reduced cost and effective performance has put organizations under pressure to redirect their strategy towards outsourcing in order to develop and focus on their core competencies. The broad objective of this study is to examine the effect of Human Resources Outsourcing on organizational performance in Deposit Money Banks. The study made use of a sample of 260 staff from 10 money deposit banks in the Asaba metropolis of Delta State, Nigeria. The research instrument was a 25 -item validated structured questionnaire of the likert type scale. A cross-sectional survey research design method was adopted, and the statistical techniques used are principle component factor analysis, correlation and multiple regression analysis. The findings showed that that there is a significant positive relationship between the variables of human resource outsourcing and organizational performance. This implies that its effect on organizational performance such as cost savings and productivity is as a result of outsourcing activities. The study therefore concludes that recruitment process outsourcing has significant relationship with organizational performance by moving the recruitment process to a recruitment agency, time is saved by the managers for more efficient planning. There is a need to adopt effective strategies when outsourcing recruitment process because human resource is the most vital asset of any organization. The study therefore recommends that Deposit Money Banks should engage in Human resource (HR) outsourcing practices, in order to get access to expert services as well as to take advantage of the excellent quality that external vendors provide and focus on their core competencies.
\end{abstract}

Keywords: human resource outsourcing, recruitment process outsourcing, training and development activities, mystery shopping and organizational performance

\section{Introduction}

The global economic instability has significantly increased and intensified the competition in several fields, forcing firms to fail, not to notice their strategies and to find novel approach to deal with the challenging environment. Outsourcing is steadily becoming a vital element of the global economy due to globalization. Dwindling resources and market competitiveness seem to have forced organizations to scrutinize their methods of manufacturing goods and services and make changes in their processes in order to enhance economic returns. To be able to survive and be profitable in current globalization era, organizations appear to have pursued continuous improvement, leaned up production, reengineered business processes, and integrated supply chains (Brannemo, 2006).

In today's competitive economic environment, the trend towards increasing added value with fewer resources and more service quality also presents a challenge for Human Resources Management in banks and other financial institutions. To survive in this era of stiff competition, firms need to adopt the strategy of outsourcing in order to focus and develop their core competencies. Over the past years there is an increasing consciousness of the significant contribution of outsourcing strategy on organizational performance (Cousins et al., 2006). Hence, organizations are forced to look for novel strategies to create value thus the concept of outsourcing. Outsourcing as a Human Resource (HR) function appears to be one of many ways to improve an organization's performance (Lawler \& Mohrman, 2003).

Therefore outsourcing represents the essential decision to reject the internalization of an activity (Franceschini, 2003) this is related to the act of sourcing from outside (Busi, 2008). Therefore with the increase in outsourcing, in the 
context of today's increasing global competition, the view of outsourcing changes from the traditional concept to strategic one. The need to react to market changes on every day basis and the complexity of forecasting the direction of such changes means that firms must focus on their core competencies and capabilities (McIvor, 2008). In this regard, outsourcing may be used as a strategy that allows firms to focus on their own core competencies by relocating all other non-core functions to outside suppliers and to strategically use outside vendors to perform services that formerly have been internal functions (Raiborn et al, 2009). Today's human resource (HR) managers are expected to shed some of their conventional roles associated with policies and procedures and the hiring, selecting, training and compensating of workforce, for more strategic roles that include customers' perception of quality, reducing overall costs of human resource administration and management of scarce resources. It is in response to this shift in paradigm, that many Human Resource Managers tend to outsource some of their functions.

Through outsourcing, firms appear to be getting new opportunities to advance their skills and competences of their employees whose jobs maybe displaced by strategic outsourcing which often move their work to lower cost regions. By outsourcing human resources functions and many menial human resource (HR) tasks, organizations seem to be able to maximise resources as well as service improvements, freeing up in-house employee to focus on more strategic staffing issues (Hindle, 2005). Practice in business and economic activities are constantly changing (Kong, 2007). Many firms have changed totally from manual processes to complex, automated and computerized technologies. Some researchers observe that service industries such as the Banking sectors have come up with sophisticated methods that require operators with special skills (Sullivan, 2006). Furthermore, many organizations are no longer as localised as they were in the past; instead finding those operating in a highly competitive market, have now devised new means at being refined through the numerous advantages of outsourcing (Gurchiek, 2005).

\subsection{The Problem}

Today, the Banking Industry is faced with fierce and intense competition due to the activities of rivals, their substitute service offerings and some government policies. As a result of these pressures, increased productivity, profitability, improved quality of service etc. are seemingly difficult to attain by some of these organisations. The irresponsiveness to the developing trend of outsourcing these functions constitutes a lot of problems.

The decision to outsource some of Human Resource (HR) functions may be encouraged for the fact that external vendors could be in a better position to provide improved profitability, efficiency and service delivery at relatively low cost than can be achieved by in-house operations, thereby increasing the competitive advantage of the firm. Finally, among the reasons for Human Resources Outsourcing is obviously to utilise and optimise management time and to become specialized in the operation of what they know how to do best (core competence), to enhance the competitive edge the firm has over its rivals, to improve service quality and to cut costs (cost reduction). The inability of firms to engage vendors to optimise and utilise the company's resources, reduce overhead cost and exceed average profit margin remain a problem.

\subsection{The Objective of the Study}

The objective of this study is to examine the effects of Human Resources Outsourcing on organizational performance in the Money Deposit Banks. The specific objectives are to:

i. ascertain the effect of recruitment process outsourcing on organizational performance.

ii. determine the influence of outsource training and development activities on organizational performance.

iii. examine the impact of mystery shopping on organizational performance

\section{Theoretical Consideration}

\subsection{Concept of Human Resources Outsourcing}

Outsourcing is a new phenomenon which is appropriate and very popular in modern organizations. Outsourcing recruitment process is mostly used to develop the performance of the organization via managerial time saving along with the cost (Corbett, 2004). Human resources (HR) perspective has changed from operational, administrative programs to strategic processes, this change has increased the focus of outsourcing the Human resources (HR) function, and it is steadily building momentum in many organizations (Merrit 2007).

Hence, outsourcing the Human resources (HR) function is seen as a essential part of modern Human resources (HR) strategy (Lohr, 2007). It has been indicated that organizations gain competitive edge over their rivals by simply shifting some of the Human resources (HR) non-core functions to outside suppliers (Beardwell \& Claydon, 2007). A positive impact is also reckoned on organizational performance by organizations who undertook the strategy of outsourcing some of their Human resources (HR) functions (Gilley, Greer \& Rasheed, 2004). More prominently 
however, research aids that outsourcing human resources (HR) activities can give confidence to the Human resources (HR) function to occur to be more strategic by spending less time on assembly cost objectives and addressing goals in terms of detailed Human resources (HR) knowledge and more time on strategic planning (Kosnik, Ji \& Hoover, 2006; Stopper, 2005).

There are a lot of reasons at both the strategic and operational level, why companies outsource their human resources (HR) activities. In particular, demand for increased productivity, profitability with reduced cost and growth as well as efficient and effective performance at customer relationship amongst others have put organizations under pressure to redirect their strategies toward outsourcing. As Greer, Youngblood, \& Gray (1999) observed, human resources (HR) outsourcing decisions are frequently a response to an overwhelming demand for reduced costs for human resources services. Downsizing and tougher competition connotes that the human resources function(s) is under increasing pressure to exhibit value in terms of performance (Roberts 2001).

Traditionally, organizations outsource service-related support functions such as payroll, invoicing, accounting, data entry, customer enquiries and record management. Even in large firms such processes can often be done more proficiently and reduced cost successfully by firms with specialised tools, amenities and systems, and with trained personnel. HR index's outsourcing services enable firms to provide work for noticeably less money and fewer overhead expenses. Therefore, not surprisingly, scholars and practitioners have supported the use of strategic outsourcing as a well-organized way to increase profits, improve new product success and performance (Rothaermel 2006; Weigelt, 2009), and speed to organizational competitiveness (Arnold, 2000; Jiang 2007).

\subsubsection{Organizational Performance}

Outsourcing certain human resource (HR) activities has a positive effect on overall performance within the company, flexibility in operations is also highly required in the modern day banking sector because there is need to react to market changes, hence this paradigm shift has called for organizations to become more dynamic and strategic in order to have a strong competitive and desirable before their customers in terms of service delivery. Organizations derive the ability to concentrate on the core HR functions of the firm by sub-contracting the non-core/peripheral activities within the organization. An activity is termed non-core or secondary if the firm lacks competence/expertise in carrying out such task or when the performance of such task costs the organization a lot of money and other resources, such activities are therefore necessarily outsourced to ease such a firm the burden thereby giving more time and concentration to other specific human resource (HR) activities. This therefore makes the option of outsourcing have a favourable effect on Organizational performance.

Competitive advantage is gained by organizations who undertake this mission to outsource some of their human resource (HR) functions. The desire to be in a more advantaged position in the industry and the ability to maintain a strategic position in the market is made possible through outsourcing. The client firm now has access to specialised services, knowledge proficiency, new technologies and methods of application which enables it to acquire competitive advantage in the industry.

The processes concerned in making the outsourcing decision helps to analyse organizational resources to unravel areas of strengths and capabilities, to strengthen them the more as well as identifying areas of weaknesses to improve on them by outsourcing them. Enhanced efficiencies and lower costs are other significant organizational outcome achieved as a result of outsourcing, with the provider's extensive experience, the firm gets access to best-practices, streamlined processes that significantly reduce transaction times and increase the speed and ability to deliver cost-effective services. Additionally outsourcing enables firms to diminish future costs by selecting the right vendor through the process of competitive bidding (Domberger, 1998). HR outsourcing also provides companies with superior flexibility and enhances productivity by using third party service providers to cover variable demands for labour (Cooke, 2001), as a result, they produce high service and enhanced customer satisfaction.

\subsubsection{Recruitment Process Outsourcing (RPO) and Organizational Performance}

Recruitment process outsourcing is a rapidly evolving model for the delivery of most human resource activities. It has to do with the situation where operational responsibility for recruiting functions of a client organization (including recruitment administration) is entrusted on a recruiting services provider from job profiling via the on-boarding of the new hire, (including technology, method, staff and reporting). It improves organization's time to hire, enhance the excellence of the candidates' pool, provides provable metrics, limit cost, etc. It reduces overhead cost; enhance the firms' competitive advantage in both the regular labour market and de-regulated labour market conditions. During economic meltdown or greater unemployment condition, recruitment process outsourcing, help companies to screen via a wider pool of candidates, (Wikipedia, 2010; Willcocks, et al 2004; Okorie, 2010). 
The Recruitment Process Outsourcing Association view RPO as follows: "when another party acts as a firm's internal recruitment function provider for a part or all of its jobs". RPO providers handle the whole recruitment/hiring processes from job profiling via the on boarding of the new hire, consisting of staff, technology, method etc. An appropriately managed RPO will enhance a company's time to hire, provide confirmable metrics, reduce costs, increase the excellence of the candidate pool and improve governmental compliances. Overtime, companies began to scrutinize how they may diminish the growing expenses of recruitment fees while still hiring hard-to-find technical specialists, and began to scrutinize the steps in the recruitment process with an eye toward outsourcing only those portions that they had the greatest difficulty and from which flowed streams of value. Organizations need to continuously search for qualified candidates when they either plan to enter new business ventures or expand on existing ones.

Employee commitment and obligation is very crucial because an employee who is loyal and committed identifies with the culture, goals, system and values of the organization. Outsourcing does not have a positive effect on employee commitment and results in the lack of a sense of belonging and connection with the organization (Sharma and Punia, 2008). Traditionally, the recruitment function have been performed internally, nevertheless, an alternative to that is the strategy of outsourcing this function to specialised firms who will take over the responsibility to provide a large pool of qualified candidates that are both keen and able to perform the required task. The scarcity of talent is one of the most crucial risks in human resource management today, and when it comes to talent acquisition, the assumed processes within the firm are not just enough, that is why many organizations are turning towards using a partner with both the proven capability and the vision to move business forward in times of change and opportunity. Well planned and executed HR practices such as orientation and learning for external recruitment agencies can augment employee dedication and in turn decrease turnover (Sharma and Punia, 2008). Human resource practices, such as recruitment, selection, appraisals and compensation have a positive effect on employee dedication (Allen and Meyer, 1997).

As outsourcing is becoming more vital its outcome can be viewed as rising turnover rates. The banking industry in Nigeria is one of the most lucrative industries which have attained unmatched success over the years. In order to enhance profitability and performance, they are acquiring novel human resource practices such as hiring external agencies for recruitment (Mansen, 2009). Corbett, (2004) discovered that companies that are facing new competition because of globalization, outsources their recruitment function in order to develop their profitability, performance and generate employment.

Thus we hypothesized that:

$\mathrm{Ha}_{1:}$ There is significant relationship between recruitment process outsourcing and organizational performance.

\subsubsection{Outsource Training and Development Activities and Organizational Performance}

The value of training to the modern corporations is clear and unquestioned. But to train in-house or to outsource is a crucial decision that is vital to configuring programs that truly hold up a firm's business objectives. Three corporate training officers discuss the latest training trends and how these can influence profitability. The typical corporation's investment in training and development grows larger each day. This is because experience shows that firms that spend more on training produce considerably more profit per employee. However, although corporate managers know that their people are the company's greatest asset, and human capital management must take on a new depth and scope to compete successfully in today's markets, it's clear that training must find superior ways to bring measurable, tangible assessment to the organization.

Outsourcing training and development actions has to do with the reassign of management and implementation of one or more ongoing training function to an external service provider. This process can grant a company a long term competitive advantage, by increasing the level of employee-knowledge and developing their capabilities; this will in turn differentiate your organization amongst others placing you at the top because of the distinctiveness of the services rendered by those well-equipped employees. Training and developing your staff is planned to build and sustain intellectual capital component of your organization, which is the foundation for developing a strong competence that will distinguish you among other rivals (Barney, 1991). Richman \&Trondson (2004) stated that outsourcing training actions also include; learning infrastructure and technology set-up, content designs and administration methods, thus enabling the employee's maximum performance. Thus, training has been seen to be a vital provider to organizational performance and success. While there has been research on the performance influence of training and of the performance impact of outsourcing in general. That notwithstanding, there are numerous ways in which such outsourcing may positively affect firm performance. One vital possible effect is cost reduction, as outsourced training provides an avenue of decreasing the fixed costs related with sustaining a training 
staff.

Furthermore, outsourcing of training can add value via the greater quality obtainable from specialized training providers. Because a lot of companies may lack the skill to carry out training in-house, better performance can be achieved with outsourced training. By outsourcing training to outside high-quality firms, companies may attain superior levels of employee productivity and performance, thus leading to greater financial performance and enhanced customer and vendor satisfaction. In a study by Bulut \& Culha, (2010) it was discovered that training is often considered as one of the most vital investments in terms of enhancing intellectual capital, which is vital for the organization's competitive sustainability.

Therefore, we hypothesized that;

$\mathrm{Ha}_{2:}$ There is a significant relationship between outsource training and development activities and organizational performance.

\subsubsection{Mystery Shopping and Organizational Performance}

The concept behind mystery shopping takes place in time when kings disguised themselves as commoners and mingled with common people. That way they were trying to learn what people were truly thinking of them and their kingdom. According to Wilson (1998), mystery shopping is an appearance of participant observation that has its start in the field of cultural anthropology. The anthropologists would participate in a tribe's daily life to have better understanding in behaviors, norms, and attitudes that were not communicable or documented via language. Mystery shopping today differs from the original anthropological approach in terms of systematic and structured format. (Wilson 1998). Surprisingly the downward trend of the economy has had a positive effect on the demand of mystery shopping.

Increased competition for the consumers' money has caused an increased necessity of mystery shopping. As the market place becomes more competitive and product and service delivery attains homogeneity, it is pertinent that differentiation through service-excellence be pursued by these organizations, a customer focus has become more and more important in today's competitive market environment; customer-satisfaction is frequently measured and also stimulated by the most current description of the quality systems requirements according to international standard organization (ISO) 9000 series, quality systems standard (ISO 2000), that is why banks engage mystery shoppers to examine 'service-delivery and customer-satisfaction margin' knowing that focus on the part of customers has altered from 'what do you sell?' to 'how do you sell it?'. In order to succeed in this phase of stiff competition, organizations are obligatory to steer towards more value added activities aimed at service quality and differentiation (Gans, 2000), and this is exactly what this strategy (mystery shopping) is out to achieve when implemented. Mystery shopping or a mystery customer is a tool used outwardly by market research firms, watchdog organizations, or internally by firms themselves to determine quality of service, or observance with regulation, or to gather detailed information about products and services, it is also known as secret shopping, performance evaluations to name a few, mystery shopping enables companies to achieve a "snapshot in time" by trained researchers who know beforehand what they are to evaluate. It provides management a method to quickly yet efficiently evaluate their business practices, deliverables, and employees from the perception of a non-bias consumer, by making use of mystery visitors, well-trained personnel who behave as normal customers but are specifically observing how well customers are treated, and the response given to them on issues they are not so clarified about.

The information provided by the mystery shoppers is used for improving the services and products to get more customers. Mystery shopping is used for various reasons. In most of the cases the goal is to determine the quality of the service delivery to the customer. The advantage of mystery shopping is in its' superiority of the measurement. The mystery shoppers should be well trained and familiar with the process.

If they are familiar with it, they are also able to measure the failure points (Hesselink, van Iwaarden \& van der Wiele 2004) Mystery shopping can be used to observe an existing service or a service that is nearly completed. The customer experience is compared to the planned experience and concept. Based on this comparison one can determine if the service concept is functional (Arantola \& Simenon 2009). Companies use the feedback and comments they get from the mystery shoppers to determine the performance of training, to understand how customers view their business, to gauge employee self-esteem and knowledge, to measure organization performance, and to review business policies and procedures (Newhouse 2004). Wilson (2001) opined that mystery shoppers use structured approach of codes and checklists to collect information and to measure service performance.

Thus we hypothesized that;

$\mathrm{Ha}_{3:}$ There is significant relationship between mystery shopping and organizational performance 


\subsubsection{Banking Industry}

The Nigeria Banking Industry has witnessed an extraordinary growth in terms of number of branches, total asset, deposit base, volume of loans and advances, particularly since the deregulation of the sector in the recent past years. However, given the nature of demand in the market, they are requisite to do more particularly in providing services as needed by their customers and other stakeholders in the industry. It is agreed that the consolidation programme were to have a positive impact in the industry, however true but has also drastically altered and redefined the nature of competition in the market, this alteration showed that mere size and degree of asset acquisition will no longer be the criteria for customers in their choice of which bank/organization to patronize or remain loyal to, rather emphasis would be based on ability to deliver advanced value (in terms of service quality) to any given customer.

Therefore the ability to react to this urgent need in the market by these organizations eventually depends on the performance of the strategies they hope to put in place to support them to realize their aim. Consequently, financial service businesses all over the globe are increasingly engaging third parties to perform those activities that would have been performed within the organization. In the Nigerian banking industry today, only sixteen deposit money banks meet up with the central banks directives. Therefore these sixteen banks are operating in the country excluding the micro finance banks. The sixteen banks are: Access bank, Diamond bank, Eco bank, FCMB, Fidelity bank, First bank, GTB, Keystone bank, Mainstream bank, Skye bank, Stanbic IBTC bank, Sterling bank, UBA, Union bank, Wema bank and Zenith bank.

\subsection{The Theoretical Framework}

The theoretical background that is used in this study is relevant to the following theories of Human Resources Outsourcing.

\subsubsection{Resource Based View (RBV) Theory}

The resource-based view (RBV) emphasizes the firm's resources as the basic determinants of performance. It adopts two assumptions in explaining sources of competitive advantage (Barney, 1991 and Peteraf and Barney, 2003). First, this model assumes that companies within an industry may be varied with respect to the collection of resources that they control. Second, it assumes that resource heterogeneity may continue over time because the resources used to execute firms' strategies are not absolutely mobile across companies (i.e., some of the resources cannot be traded in factor markets and are complicated to accumulate and emulate). Resource heterogeneity is seen as a fundamental condition for a resource bundle to add to a competitive advantage. The argument goes "If all firms in a market have the same store of resources, no strategy is available to one organization that would not also be available to all other organization in the market" (Cool, Almeida Costa and Dierickx, 2002).

Like the Chicago School tradition, the RBV is an efficiency-based enlightenment of performance differentials (Barney, 1991; Conner, 1991; Teece, Pisano and Shuen, 1997; Peteraf and Barney, 2003). Performance differentials are seen as derived from rent differentials, attributable to resources having essentially diverse levels of competence in the sense that they allow the companies to deliver superior benefits to their customers for a given cost (or they can offer the same benefit levels for a lesser cost) (Peteraf and Barney, 2003). The assumed heterogeneity and serenity are not, however, adequate circumstances for continued competitive advantage.

According to Barney (1991), a firm resource must be rare, valuable, incorrectly imitable and substitutable in order to be source of a sustainable competitive advantage. In her 1993's paper, Peteraf presents four conditions core sustained competitive advantage: superior resources (heterogeneity within an industry), ex post frontier to competition, unsatisfactory resource mobility and ex ante limits to competition. Much resource-based research has focused on insubstantial assets, which consist of information (Sampler, 1998), knowledge (e.g. Spender, 1996), and self-motivated capabilities (Teece, Pisano and Shuen, 1997). The inference of this theory indicates that firm's resources are the basic determinants of performance. Performance differentials are seen as derived from rent differentials, attributable to resources having essentially diverse levels of competence which allow companies to deliver superior benefits to their customers at a lower cost

\subsubsection{Agency Theory}

Agency theory (Fama, 1980; Jensen and Meckling, 1976) has been used to examine organizational performance and managerial decision making (Christen, Iyer, \& Soberman, 2006). Agency theory can be functional to situations in which there is a delegation of work by one party (the principal) to another (the agent), who performs the work (Eisenhardt, 1989). For our purposes the principal is the purchaser or outsourcing firm and the agent is the vendor or outsourcing provider. The units of analysis differ from owner and manager and manager and employee relationships most often found in the literature, but are consistent with the conceptual framework (Milgrom and Roberts, 1992; 
Whitener, Brodt, Korsgaard, and Werner, 1998).

There are two sources of agency problems: those arising from asymmetric information such as moral vulnerability and unfavorable selection and those arising from asymmetric interests among the principal and the agent (goal conflict). Goal conflict includes problems of risk sharing among the principal and the agent due to differing risk preferences. Alchian and Demsetz (1972) addressed one problem resulting from asymmetric information (informational problems of monitoring effort in team production) in their suggestion that team production is a reason why firms emerge. Moral hazard "arises from the problem that individuals will sometimes say what they do not mean or what they know not to be true," while adverse selection "stems from the fact that individuals sometimes do things they said they will not do or do not do things they said they would" (Ben-Ner, Montias, and Neuberger, 1993). Williamson's (1985) transaction cost framework considers moral vulnerability as post-contractual opportunism whereas unfavorable selection is deemed to be pre-contractual opportunism. Eisenhardt (1989:61) refers to moral hazard simply as the "lack of effort on part of the agent" and adverse selection as the "misrepresentation of ability by the agent".

Both problems are appropriate to the current state of HRO as vendors signing increasingly large contracts to replace whole HR departments are entering into uncharted waters and client firms face the risk of vendors misrepresenting their ability and underperforming on contract of five to seven years in duration. Agency theory predicts that parties seek to determine the most efficient contract given their assumptions and boundary conditions, by assuming that individuals are self interested, risk averse, and act with bounded rationality. Information asymmetry between principals and agents is a source of gain to the party with better information and a source of goal conflict. The outsourcing organization is the source of much of the relevant information about the costs of providing a given HRM service. In many cases HR consultancies are paid to acquire information about the efficiency and effectiveness of HRM process for an organization. The HR consultancy has an inducement to hold back or alter some of this information, particularly if their organization or an allied body is selling HRO services. This theory help to predict how parties seek to establish the most efficient contract given their assumptions and boundary conditions, by assuming that individuals are self interested, risk averse, and act with bounded rationality.

\subsection{Summary of Theoretical Consideration}

The foregoing contributions to the literature on human resources management examined the concepts of human resources outsourcing, organizational performance and the theoretical framework on which this study is anchored on. As a preamble to the understanding of these concepts, a general view of basic issues on human resources outsourcing and organizational performance were taken with particular emphasis on recruitment process outsourcing, outsource training and development and mystery shopping. This resulted to highlighting various conceptualizations and constructs of human resources outsourcing. Specifically contributions were identified in the areas of their attributes.

The trend towards improved added value and organizational performance, has elicited increasing awareness to determine strategies to maximize resources and quality service improvements. In this regard, so many organizations seem no longer as localized, the view of outsourcing changes from traditional to strategic concept. Thus the perspective of outsourcing appears to alter from mere administrative and operational programmes to strategic processes. Thereby increasing the focus on outsourcing in most outfits.

At both strategic and operational levels, there are various justifications why companies are involved in outsourcing: Specifically, by outsourcing non core / peripheral activities, organizations derive their abilities to mainly concentrate on the very core human resources functions. The quest for strategic positioning towards enhanced efficiencies, lower costs and access to best practices are significant outcomes attained through outsourcing practices. This affords organizations the opportunities to advance their employees competences.

The theoretical framework adopted in this study is anchored on Resource Based View and Agency theories which are germane to human resources outsourcing practices. These theories represent both intellectual backdrop and instrumental mechanisms of this study. The implication indicates that firm's resources, attributable to having essentially different levels of competences are basic determinants of organizational performance, which enables companies to deliver superior benefits to customers. Outsourcing decisions help to analyze firms resources and to unravel areas of weaknesses to improve on through outsourcing.

Although the extant literature seems not to provide support for flexibility in operations in contemporary banking, however the need to respond to dynamic marketing imperatives has elicited a paradigm shift for organizations to become more strategic. This will ensure that organizations will be positioned to be competitive and efficient in customer service delivery. 


\section{The Methodology}

The cross-sectional survey research design method was adopted. The study covered 10 deposit money banks operating in Asaba metropolis in Delta State, Nigeria, with a total population of 750 employees, with the aid of sample frames from the human resource departments of each bank. Out of which the total 260 staff were selected as the sample objects through stratified random sampling technique. The research instrument was a 15 item validated structured questionnaire. All the items were adequately assessed on a five-point balanced likert scale.

\section{Results}

In order to validate the research instrument, Straubs (1989) process of validating research instruments in MIS research was adopted in terms of convergent and discriminate validity. Thus a Principle Component Factor Analysis (CFA) with varimax rotation was conducted to investigate the distinctions among recruitment process outsourcing, outsource training and development activities, mystery shopping and organizational performance of the measurement scales as depicted in table 1 . All factor loadings exhibited values that are above 0.70 for each construct, indicating a strong goodness of fit. Thus the instrument demonstrated convergent validity. Therefore the result showed that each of the three constructs is unidimensionally and factorialy distinct and that all items used to operationalise a particular construct are loaded to single factor. As shown in Table 1, the instrument demonstrates convergent validity with factor loadings exceeding 0.07 for each construct.

Table 1. Factor analysis results: Principal component extraction

\begin{tabular}{lllll}
\hline $\begin{array}{l}\text { Scale } \\
\text { items }\end{array}$ & $\begin{array}{l}\text { Recruitment } \\
\text { process } \\
\text { outsourcing } \\
\text { (RPO) }\end{array}$ & $\begin{array}{l}\text { Outsource } \\
\text { training and } \\
\text { development } \\
\text { activities } \\
\text { (OTDA) }\end{array}$ & $\begin{array}{l}\text { Mystery shopping } \\
(\mathrm{MS})\end{array}$ & $\begin{array}{l}\text { Organizational } \\
\text { performance } \\
(\mathrm{OP})\end{array}$ \\
\hline RPO & 0.814 & & \\
\hline RPO & 0.776 & & & \\
\hline RPO & 0.832 & & & \\
\hline RPO & 0.835 & 0.863 & & \\
\hline OTDA & 0.784 & 0.852 & \\
\hline OTDA & 0.823 & 0.821 & 0.761 \\
\hline OTDA & 0.785 & 0.811 & 0.819 \\
\hline OTDA & & 0.721 & \\
\hline MS & & & \\
\hline MS & & & \\
\hline MS & & & \\
\hline MS & & & \\
\hline OP & & & \\
\hline OP
\end{tabular}

Suppress absolute values $<0.05$

For the reliability check; the test-retest method was used to estimate the internal consistency. This involves repeated administration of the same type of questionnaire. In this regard, the same questionnaire was administered twice to same respondents at interval of three weeks. The reliability was established by assessing the internal consistency of the items representing each construct, using cronbach alpha index. Favourable reliable scores were obtained from all the items since all co-efficient values were above 0.6. Thus exceeding the minimum benchmark of cronbach alpha value (0.6) recommended by Malhotra (2004). 
Table 2. Correlation matrix among the dimensions of human resource outsourcing and organizational performance

\begin{tabular}{|c|c|c|c|c|}
\hline Variables & 1 & 2 & 3 & 4 \\
\hline $\begin{array}{l}\text { 1. } \\
\text { Outsourcing }\end{array}$ & 1 & & & \\
\hline $\begin{array}{ll}\text { 2. } & \text { Outsource Training and } \\
\text { Development Activities }\end{array}$ & $.795^{* *}$ & 1 & & \\
\hline 3. Mystery Shopping & $.786^{* *}$ & $.729^{* *}$ & 1 & \\
\hline 4. Organizational Performance & $.926^{* *}$ & $.853^{* *}$ & $.850^{* *}$ & 1 \\
\hline
\end{tabular}

**Correlation is significant at the 0.01 level (2-tailed)

The correlation analysis as shown in table 1 reported that recruitment process outsourcing exhibited positive and significant correlation with organizational performance $\left(\mathrm{r}=.926^{* *}, \mathrm{P}<.01\right)$. Outsource training and development activities also exhibited positive correlation with organizational performance $\left(\mathrm{r}=.853^{* *}, \mathrm{P}<.01\right)$. Finally, mystery shopping exhibited positive and significant correlation with organizational performance $\left(\mathrm{r}=.850^{* *}, \mathrm{P}<.01\right)$.

Table 3. Multiple regression analysis of dimensions of human resource outsourcing and organizational performance

\section{Coefficients $^{\mathrm{a}}$}

\begin{tabular}{|c|c|c|c|c|c|c|}
\hline \multirow{2}{*}{\multicolumn{2}{|c|}{ Model }} & \multicolumn{2}{|c|}{ Unstandardized Coefficients } & \multirow{2}{*}{$\begin{array}{c}\begin{array}{c}\text { Standardized } \\
\text { Coefficients }\end{array} \\
\text { Beta }\end{array}$} & \multirow[b]{2}{*}{$\mathrm{t}$} & \multirow[b]{2}{*}{ Sig. } \\
\hline & & B & Std. Error & & & \\
\hline \multirow[t]{4}{*}{1} & (Constant) & -2.245 & .423 & & -5.308 & .000 \\
\hline & $\begin{array}{l}\text { recruitment process } \\
\text { outsourcing }\end{array}$ & .562 & .037 & .533 & 15.018 & .000 \\
\hline & $\begin{array}{l}\text { outsourcing training and } \\
\text { development activities }\end{array}$ & .255 & .033 & .247 & 7.696 & .000 \\
\hline & mystery shopping & .298 & .037 & .251 & 7.985 & .000 \\
\hline
\end{tabular}

a. Dependent Variable: organizational performance

Table 4. Model summary

\begin{tabular}{llrrrr}
\multicolumn{4}{c}{ Model Summary } \\
\hline Model & $\mathrm{R}$ & R Square & $\begin{array}{c}\text { Adjusted R } \\
\text { Square }\end{array}$ & $\begin{array}{c}\text { Std. Error of the } \\
\text { Estimate }\end{array}$ \\
\hline 1 & $.958^{\mathrm{a}}$ & .917 & .916 & .4789
\end{tabular}

a. Predictors: (Constant), mystery shopping, outsourcing training and development activities, recruitment process outsourcing

\section{Discussion}

The study is focused on enhancing organizational performance through human resource outsourcing. The results of the correlation analysis involving all the indicators of human resource outsourcing reported positive correlation coefficient values among the measures. This indicated that they are appropriate dimensions of human resource outsourcing. The results from the multiple regression analysis recorded the effect of human resource outsourcing on organizational performance. The three variables of human resource outsourcing; recruitment process outsourcing $(\beta=.533 ; \mathrm{P}<.01)$, outsourced training and development activities $(\beta=.247 ; \mathrm{P}<.01)$, mystery shopping $(\beta=.251 ; \mathrm{P}<.01)$ exhibited statistically significant positive effect on organizational performance. Table 4 showed that change in 
organizational performance is brought about by human resource outsourcing by $92 \%$ as indicated by the adjusted $\mathrm{R}^{2}$ value.

The result provided support for the $\mathrm{H}_{1}$ test result which indicated that there is significant positive relationship between recruitment process outsourcing and organizational performance $(0.000<0.05)$. This is consistent with Corbett, (2004) assertion that companies that are facing new competition because of globalization can outsource their recruitment function in order to enhance their profitability, performance and generate employment.

Similarly the findings indicated that outsourced training and development activities is found to have significant positive relationship with organizational performance $(\beta=.247 ; \mathrm{P}<.01)$. The findings provided support for the result of $\mathrm{H}_{2}$ which showed that there is a significant positive relationship between training and development activities and organizational performance $(0.000<0.05)$. This is in agreement with Okorie, $(2010)$ view that outsourced training \& development activities has positive effect on organizational performance. The implication of the above findings is that outsourcing of training can add value via the greater quality available from expert training providers. This is because many banks may be short of the expertise to carry out in-house training. Performance and better performance may be obtained with outsourced training. By outsourcing training to outside specialist firms, banks may attain higher levels of employee productivity and performance, thus leading to greater financial performance and improved customer and vendor satisfaction. Improved training also enhances Organizational performance because well-trained employees have a better knowledge foundation for improving processes and products. In addition, by outsourcing training activities, the company will be able to concentrate on the core value-creating activities that drive competitive advantage.

In the same vein, mystery shopping has positive effect on organizational performance $(\beta=.251 ; \mathrm{P}<.01)$. This finding provides support for result $\mathrm{H}_{3}$ test which indicated that mystery shopping has significant relationship with organizational performance $(0.000<0.05)$. This is in agreement with the findings of Tutt Woods $(2010)$, that mystery shopping provides vital information for businesses and leads organizations to efficient performance. Due to the downward economy of today, businesses can't afford to lose any customers. The consumers' growing demand for high-quality service and more intense competition in businesses increase the demand for mystery shopping.

\section{Conclusion}

From the findings of the study, it can be concluded that, overall the Human Resources Outsourcing had a significant impact on the organizational performance of the Banks.

Specifically, recruitment process outsourcing has significant relationship with organizational performance. By moving the recruitment process to a recruitment agency a lot of time is saved by the managers for more efficient planning. There is a need to discover strategies when outsourcing recruitment process because human resource is the most crucial asset of any organization. The cost of training and recruiting is influenced by well planned, employee turnover and executed HR practices such as learning and orientation for external recruitment agencies can augment employee commitment and in turn decrease turnover.

The outsourced training \& development activities have a significant positive relationship with organizational performance. Training has been seen to be a significant contributor to organizational performance and success. That notwithstanding, there are several ways in which such outsourcing may positively affect firm performance. One crucial likely effect is cost reduction, as outsourced training provides a means of limiting the fixed costs related with sustaining training staff.

Mystery shopping outsourcing had a significant positive relationship with organizational performance. This is because mystery shopping provides vital information for businesses and leads organizations to efficient performance. Due to tough competition experienced today, banks can't afford to lose any customer. The consumer's growing demand for high-quality service and more intense competition in the banking industry has increased the demand for mystery shopping in banks. The information provided by the mystery shoppers is used for improving services and products to get more customers.

\section{Recommendations}

The recommendations made flow from the findings of the study and constitute the researcher's advice to Banks for improving their operations and organizational performance.

Banks should engage in Human resource (HR) outsourcing so as to take advantage of the use of expert services as well as to capitalize on the outstanding quality that external firms provide in performing the human resource (HR) functions. 
Bank managers should take into account the variables considered since the results show that there is a significant relationship between the human resource (HR) outsourcing and organizational performance in the Nigerian deposit money banks. Banks should move the recruitment process to a recruitment agency so as to save lots of time by the managers for more efficient planning.

Banks should outsourced their training \& development activities since its potential impact is cost reduction, as outsourced training provides an opportunity of decreasing the costs related with employee training and development.

\section{References}

Alchian, A. A., \& Demsetz, H. (1972). Production, information costs, and economic organization. American Economic Review, 62(5), 777-795.

Beardwell, J., \& Claydon, T. (2007).Human Resource Management: A contemporary approach (5th ed.). New York: Prentice Hall.

Bulut, C., \& Culha, O. (2010). The Effects of Organizational Training on Organizational Commitment. International Journal of Training and Development, 14(4), 309-322. https://doi.org/10.1111/j.1468-2419.2010.00360.x

Conner, K (1991). A Historical Comparison of Resource-Based Theory and Five Schools of Thought Within Industrial Organization Economics: Do We Have a New Theory of the Firm?, Journal of Management, 17(1), 121-154. https://doi.org/10.1177/014920639101700109

Cook, M.F. (1999) Outsourcing Human Resources Functions: Strategies for Providing Enhanced HR Services at Lower Cost. New York. AMACOM

Cool, K., Almeida, C.L., \& Dierickx, I. (2002). Constructing Competitive Advantage. In Pettigrew, Andrew, Thomas, Howard and Whittington, Richard (Eds.), Handbook of Strategy and Management. Sage publications.

Corbett, F.M. (2004). The 2001 Strategic Outsourcing: The Outsourcing Research Council. Michael F. Corbette \& Associates.

Eisenhardt, K.M. (1989). Agency theory: An assessment and review. Academy of Management Review, 14, 57-74.

Fama, E. (1980). Agency problems and the theory of the firm. Journal of Political Economy, 88(2), 288-307. https://doi.org/10.1086/260866

Gans, N. (2002). Customer Loyalty and Supplier Quality Competition. Management Science, 48(2), 207-221. https://doi.org/10.1287/mnsc.48.2.207.256

Gilley, K.M., Greer, C.R., \& Rasheed, A.A. (2004). Human Resource Outsourcing and Organizational Performance in Manufacturing Firms. Journal of Business Research, 57, 232-240. https://doi.org/10.1016/S0148-2963(02)00304-1

Greer, C. R., Youngblood, S. A., \& Gray, D. A. (1999). Human Resource Management Outsourcing: The Make or Buy Decision. Academy of Management Executive, 13(3), 85-96. https://doi.org/10.5465/AME.1999.2210317

Gurcheik, K. (2005). Record Growth in Outsourcing of HR Functions. HR magazine, 50(6), 35.

Hesselink M., Wiele A. van der, \& Boselie P. (2004). The Importance of Customer Satisfaction in Organizational Transformation: a case of a Dutch Temporary Employment Agency. ERIM Report Series Research in Management, ERS-2002-60-ORG.

Hindle, J. (2005). HR Outsourcing in Operation; Critical Success Factors. Human Resource Management International Digest, 13(35), 39-42. https://doi.org/10.1108/09670730510595058

Holcomb, T. R., \&Hitt, M. A. (2007) Toward a Model of Strategic Outsourcing. Journal of Operations Management, 25(2), 464-481. https://doi.org/10.1016/j.jom.2006.05.003

Jensen M., \& Meckling W. (1976). The theory of the firm: Managerial behavior, agency costs, and capital structure. Journal of Finance Economics, 3, 305-360. https://doi.org/10.1016/0304-405X(76)90026-X

Kong, T. (2007). A Selective Review of Recent Development in the Economic Growth Literature. Asian-Pacific Economic Literature, 2(1). https://doi.org/10.1111/j.1467-8411.2007.00190.x

Kosnik, T., Ji, D.J.W., \& Hoover, K. (2006). Outsourcing vs. in Sourcing in the Human Resource Supply Chain: A Comparison of Five Generic Models. Personnel Review, 35(6), 671. https://doi.org/10.1108/00483480610702728 
Lado, A. A., \& Wilson, M. C. (1994). Human Resource Systems and Sustained Competitive Advantage: A Competency-Based Perspective. Academy of Management Review, 19, 699-727.

Lohr, S. (2007). At IBM: A Smarter Way to Outsource. New York Times, 1, July 5.

Malhotra, N.K. (2004). Marketing Research: An Applied Orientation. Delhi: Pearson Education.

Merritt, L. (2007). Human capital management: More than HR with a New Name. Human Resource Planning, 30(2), 14-16.

Milgrom, P., \& Roberts, J. (1995). Complementarities and fit: Strategy, structure, and organizational change in $\begin{array}{llll}\text { manufacturing. Journal of Accounting and Economics, 19, } & \text { 19-208. }\end{array}$ https://doi.org/10.1016/0165-4101(94)00382-F

Okorie N.E. (2010a). Growing Corporate Excellence and Performance Using Business Process Outsourcing Model. Issues, Dimensions, Challenges and Prospects

Peteraf, M., \& Barney, J. (2003). Unraveling the Resource-Based Tangle. Managerial and Decision Economics, 24, 309-323. https://doi.org/10.1002/mde.1126

Pfeffer, J. (1994). Competitive Advantage through People: Unleashing the Power of the Work Force. Boston: Harvard Business School Press.

Robert France Group. (2004). An Overview of HR Business Process Outsourcing (BPO). Retrieved May 4, 2006, from http://www.frgonline.com/subsforum/archive/daily/082304/082604nt.ht

Sampler, J. (1998). Redefining Industry Structure for the Information Age. Strategic Management Journal, 19(4), 343-355.

Spender, J.-C. (1996). Making Knowledge the Basis of a Dynamic Theory of the Firm. Strategic Management Journal, 17, Special Issue, 45-62. https://doi.org/10.1002/smj.4250171106

Stopper, W.G. (2005). Outsourcing's Effect on HR Leadership Development. Human Resource Planning, 28(4), 11-13.

Sullivan, J. (2006). HR goes MIA at HP. Workforce Management, 85(18), 50.

Teece, D., Pisano, G., \& Shuen, A. (1997). Dynamic capabilities and strategic management. Strategic Management Journal, $\quad 18(7)$ 509-533. https://doi.org/10.1002/(SICI)1097-0266(199708)18:7<509::AID-SMJ882>3.0.CO;2-Z

Ulrich, D. (1996). Human Resource Champions. Boston: Harvard Business Review.

Whitener, E. M., Brodt, S. E., Korsgaard, M.A., \& Werner, J.M. (1998). Managers as initiators of trust: An exchange relationship framework for understanding managerial trustworthy behavior. Academy of Management Review, $23,513-530$.

Wikipedia. (2010). Offshore Outsourcing/Information on Offshore Outsourcing Resources Process Issues. Retrieved 28th April 2010, from http://www.offshoreoutsourcing.org

Willcocks, L., Hindle, J., Feeny, D., \& Lacity, M. (2004). IT and Business Process Outsourcing: The Knowledge Potential, Information Systems Management. European Management Journal, 21(2), 7-15.

Williamson, O. (1985). The Economic Institutions of Capitalism: Firms, Markets and Relational Contracting. New York: Free Press.

Wilson, A.M. (1998). The Role of Mystery Shopping in the Measurement of Service Performance. Managing Service Quality, 8(6), 414-420. https://doi.org/10.1108/09604529810235123

Wright, P. M., \& McMahan, G. C. (1992).Theoretical Perspectives for Strategic Human Resource Management. Journal of Management, 18(2), 295-320. https://doi.org/10.1177/014920639201800205 